\title{
Relationship between Work Motivation and Organizational Culture in Enhancing Professional Attitudes of Pakuan University Lecturers
}

\author{
Yudhie Suchyadi \\ University of Pakuan, Bogor, Indonesia \\ Corresponding Author: ydhie.schyadi@gmail.com
}

\begin{abstract}
The objectives of this study was to examine the relationship between work motivation, organizational culture toward lecturers professional attitudes. The research was conducted at study program of Pakuan University. The applied research methods are survey method and data analysis technique using the correlation and simple linier regression as well as correlation and multiple linier regression statistical. This research can be classified into correlation research which consist of two independent variables namely work motivation, organizational culture and one dependent variable namely lecturers professional attitudes. This research involved samples of 166 permanent lecturers which were selected by proportional random sampling. Meanwhile, the hypothesis test is conducted on 0.05 significance level. Results emerged that there is a positive relationship between all variables tested in the study. First, there is a positive and significant correlation between the work motivation with the lecturers professional attitudes with regression equation of $\hat{\mathrm{Y}}=-1.79+1,04 \mathrm{X} 1$ and correlation coefficient ry $1=0.997$. The contribution of the work motivation toward the lecturers professional attitudes is $99,7 \%$. Second, there is a positive and significant between correlation the organizational culture with the lecturers professional attitudes with regression equation of $\hat{Y}=-3,06+$ $1,02 \mathrm{X} 2$ and correlation coefficient ry $2=0.997$. The contribution of the organizational culture toward the lecturers professional attitudes is $99,7 \%$. Third, there is a positive and significant correlation between the work motivation with organizational culture combined with the lecturers professional attitudes with regression equation of $\hat{Y}=-2,634+0,528 X 1+0,505 X 2$ and correlation coefficient ry $12=0,998$. The contribution of the work motivation and organizational culture toward the lecturers professional attitudes is $99,8 \%$. Based on the results above it can be concluded that the lecturers professional attitudes can be improved through a high working motivation and the organizational culture
\end{abstract}

Keywords: professional attitudes, work motivation, organizational culture

\section{INTRODUCTION}

Education is the most important factor and a top priority that requires serious attention from all parties, because education is a determinant of the nation's progress in the future. National goals and ideals, for the intellectual life of the nation is contained in the 1945 Constitution. The government together with the community continues to seek the development of education for the realization of an independent, superior and ready nation to face the globalization world.

In the current condition and globalization era, the position of the lecturer in its function as the nation's intelligence and advancing the education world, the professional attitude of the lecturer should always be improved because in addition to his regular activities as a lecturer, it must also be able to display his professional competence in carrying out his functions.

Attitude plays a big role in human life, because if an attitude has been formed in the human self then that attitude will follow to determine how to behave towards the objects around it. According to Mann in Azwar (2007), attitudes are an evaluative predisposition that much determines how individuals act, but actual attitudes and actions are often much different. This is because the real action is not only determined by the attitude alone but also determined other external factors. As an educator, professional lecturers as well as role models should maintain the image in behaving and behaving.

Attitudes are predispositions learned from an individual to respond positively or negatively with moderate intensity and or adequacy to objects, situations, concepts, or others. Bruno in Shah, suggests that attitude is a relatively settled tendency to react in a certain way (Muhibin 2003).

There are factors that will shape human attitudes, namely personal experience, culture, other important people, mass media, religious institutions or institutions, and emotional factors within the 
individual. According to Robbins (2003), the work environment also influences attitudes in one's work, how the working environment climate, the leadership's attention to employee performance, how social conditions or members of peer groups. It has also been suggested that as a source of attitudes comes from parents, educators, members of peer groups, popular individuals who are admired.

According to Mukhtar and Priambodo (2001), professional educators are educators with a career and a professional soul with a special set of expertise through education or training, legalized by a certificate by an institution or institution.

According to M. Uzer Usman (2005), the notion of professional educator is a person who has special skills and expertise in the field of teacher training so that people are able to perform their duties and functions as educators with maximum ability, or professional educators are well educated and trained, rich in their fields. Educated and trained not only get formal education but also have to master various strategies or techniques in teaching and learning activities and mastering educational foundations. Professional educators should have attitudes and behaviors that can be role models for learners, able to develop competence in themselves, and able to develop the potential of learners.

Professional competence of educator is ability and authority of educator in running profession teacher. Educators who are skilled and skilled in carrying out their profession can be called as competent and professional educators. The professional competence of the educator illustrates the abilities that a qualified person must possess (M. Uzer, 2005).

Motivation is generally known as encouragement or willingness to do something. Motivation is a psychical aspect that can help to set choices for objects that can be chosen. With the support of high motivation to perform an action related to the purpose, it is expected that goal can be achieved.

Motivation is a psychological process that reflects the interaction between attitudes, needs, perceptions, and the satisfaction that occurs in a person. Motivation is a force or a factor within a person, which raises, directs, and organizes his behavior. Motivation is the thing that causes, distributes, and supports human behavior in order to work hard and enthusiastically achieve the desired results (M. Hasibuan, 2003).

In relation to work motivation of lecturers, there are some wishes and needs that must be met by lecturers so that the lecturers are motivated to work. Susilo (2000) states that there are some employee wishes (lecturers) that must be fulfilled in work that is: 1). Salary / wages, 2) .Excellent jobs economically, 3) .Compact partners, 4). which is run, 5) .That work is meaningful, 6) .The opportunity to go forward, 7) .The working conditions are safe, comfortable and attractive,
8) .Leaders and fair wise, 9) .Areful hearing and command, 10). Organizations / workplaces that people value.

Culture is a life view that is shared by a community group. Culture can be interpreted as a whole system of ideas and feelings, actions and works produced by human beings in the life of society that belonged to him through the learning process in accordance with ethnic, professional and regional peculiarities (Sudarwan, 2003).

According to Robbins (2003), organizational culture is a system of shared meanings of shared values and shared by the organization, which serves to create a clear distinction between one organization and another, creates a sense of identity for members of the organization, facilitates the emergence of a collective commitment to organization, enhancing social system stability, and creating mechanisms of meaning and control that guide the attitude and behavior of members of the organization. Deal and Kennedy as quoted by Robbins explain the organizational culture as the dominant values supported by the organization.

Schien (1992) divide organizational culture into several indicators such as: qualitative (basic) aspects, quantitative aspects (shared) and aspects of formation, assumption and beliefs, external adaptation and integration internal (internal integration) as a process of cultural unification through assimilation of the organizational culture that enters and influences the character of members. According to Desmond Graves there are ten indicators of organizational culture: (1) self-assurance, (2) firmness in decisiveness, (3) supervisory abilities, (4) emotional intelligence (intelegence), (5) initiative, (6) need for achievement, (7) need for self actualization, (8) needs of position / position (need for power), (9). need for reward, (10). need for security. One step ahead of Bennet Silalahi's review of work culture can be seen from the perspective of theology and deontology such as the views of Konfutse's philosophy, Christian ethics and the principles of Islam

Starting from that, need to be pursued a research to reveal professionalism of lecturer seen from factors related to attitude variable to profession lecturer.

\section{RESEARCH METHODS}

This study aims to examine the attitudes of professional lecturers and variables that have a relationship with the professional attitude of lecturers, in this case is the work motivation $\left(\mathrm{X}_{1}\right)$, and organizational culture $\left(\mathrm{X}_{2}\right)$ and efforts to improve the professional attitude $(\mathrm{Y})$ of lecturers.

Specifically this research aims to know:

1. The relationship between work motivation and professional attitude of lecturer

2. The relationship between organizational culture and professional attitude of lecturer. 
3. The relationship between work motivation and organizational culture together with professional attitude of lecturer.

Besides, this study aims to find the weak elements of the independent variables that have a positive relationship with the professional attitude of lecturers in the University of Pakuan.

This research requires research instruments used to collect data that is 1.Instruments motivation work lecturers, 2.Instrumen professional attitude, 3. Instrumen organizational culture

\section{RESULTS AND DISCUSSION}

The relationship between work motivation and professional attitude of lecturer in the program environment of Pakuan University

From the results of hypothesis testing shows that there is a functional relationship between work motivation with professional attitude of lecturer with regression equation $\hat{\mathrm{Y}}=-1.79+1,04 \mathrm{X}_{1}$ with value $\mathrm{F}$ observe $=40843,47>$ F-table $(\alpha=0,05)=3,989$ dan F-table $(\alpha=0,01)=6,792$, which means that regression significance is very significant. The functional relationship is linear in form with linearity test with value F-observe $=0,459<$ F-table $(\alpha=0,05)=1,452$ dan F-table $(\alpha=0,01)=1.694$ which means non significant or regression is linear. The resulting correlation coefficient of 0.997 indicates that any increase in motivation score will improve professional attitude.

The coefficient of determination between work motivation and professional attitude of lecturer is $\mathrm{R}_{\mathrm{y} 1}{ }^{2}$ $=0,997$. This means that $99.7 \%$ professional attitude of lecturers is the result of the work motivation of lecturers, while $0.3 \%$ is contributed by other variables that have relationship with the improvement of professional attitude of lecturer. The findings obtained in this study indicate that the motivation of the lecturer is the attitude of the lecturer in performing his duties and functions as a lecturer who is able to develop the competence in him and able to develop the potential of the learners and master the various strategies or techniques in teaching and learning activities, the foundation of education.

This is in accordance with the theory put forward by Uzer Usman that professional lecturers are well-educated and trained people, that is not only to get formal education but also to master various strategies or techniques in teaching and learning activities and master the foundations of education, able to be exemplary for learners, able to develop competence in him, and able to develop potential of learners and have rich experience in their field. Attitudes and behavior of lecturers are influenced by several factors, in the form of external and internal factors. Therefore lecturers must be able to overcome if both of these factors cause negative things. Professional attitude of lecturers has a great function in the process of education in school. Thus a professor who has a high professional attitude will be able to improve his performance. The results of previous studies have also proved that the motivation of lecturers' work has a positive relationship with the professional attitude of lecturers, one of which is the study of Made Ridha in his analysis proves there is a significant determination between work motivation and professionalism of public elementary school teachers in Gugus II Kecamatan Sukasada, Kabupaten Buleleng with correlation coefficient of 0.564 and effective contribution of $14.7 \%$. This means that the higher the motivation of the lecturer work the higher the result of professional attitude of the lecturer, and vice versa, the lower the work motivation of the lecturer, the lower the result of professional attitude of the lecturer. Thus the findings of facts and data in the analysis of this study increasingly support the previous findings on the existence of a positive relationship between professional attitudes with the motivation of lecturer work.

The relationship between organizational culture and professional attitude of lecturer in the program environment of Pakuan University

From the results of hypothesis testing showed that there is a functional relationship between organizational culture with professional attitude of lecturer with regression equation $\hat{\mathrm{Y}}=-3,06+1,02 \mathrm{X}_{2}$ with value F-observe $=40263,445>$ F-table $(\alpha=0,05)$ $=3,899$ and F-table $(\alpha=0,01)=6,792$ which means that regression significance is very significant. The functional relationship is linear in form with linearity test with F-observe $=0,003<$ F-table $(\alpha=0,05)=$ 1,454 dan F-table $(\alpha=0,01)=1,697$ which means non significant or regression is linear. The value of correlation coefficient generated equal to 0.946 indicates that any improvement of organizational culture score will improve professional attitude of lecturer.

The coefficient of determination between organizational culture and professional attitude of lecturer is $\mathrm{R}_{\mathrm{y} 2}{ }^{2}=0,9938$. This means that $99.38 \%$ professional attitude of lecturers is the result of the workings of organizational culture, while $0.62 \%$ is contributed by other variables that have relationship with the improvement of professional attitude of lecturer. The findings obtained in this study indicate that organizational culture is a system of shared meanings of values that serve to create a clear distinction between one organization and another, and facilitate the emergence of commitment as well as dominant values that have the main characteristics.

This is consistent with the theory put forward by Stepen P.Robbin that organizational culture is a shared system of shared values and shared values of the organization, which serves to create a clear distinction 
between one organization and another, creating a sense of identity for members of the organization, facilitate the emergence of a collective commitment to the organization, enhance the stability of social systems, and create mechanisms of meaning and control that guide the attitude and behavior of members of the organization.

Taliziduhu Ndraha states that organizational culture is a set of basic assumptions and beliefs received by members of an organization developed through the process of learning from external adjustment problems and internal integration.

Organizational culture serves as a mechanism of meaning-making and control that guides and assists organizational members about how to think, feel, and behave correctly and appropriately. Thus, schools with high organizational culture will be able to improve the professional attitude of lecturers.

The results of previous studies have also proved that organizational culture has a positive relationship with professional attitude of lecturers, one of them is study from Inayatulah, showing the contribution of organizational culture to professional teacher of $15.44 \%$.

This means that the better the organization culture the higher the results of professional attitude of lecturers, and vice versa, the less good the organizational culture the lower the professional attitude of the lecturer.

Thus the findings of facts and data in the analysis of this study further support the previous findings on the existence of a positive relationship between organizational culture and professional attitude of lecturers.

The relationship between work motivation of lecturers and organizational culture together with professional attitude of lecturer in environment of study program of Pakuan University

From the results of hypothesis testing showed that there is a functional relationship between work motivation and organizational culture together with professional attitude of lecturer with regression equation $\hat{\mathrm{Y}}=-2,634+0,528 \mathrm{X}_{1}+0,505 \mathrm{X}_{2}$ with value F-observe $=18084,5>$ F-table $(\alpha=0,05)=3,051$ and F-table $(\alpha=0,01)=4,738$ which means that regression significance is very significant. The value of multiple correlation coefficient between work motivation and organizational culture together with professional attitude of lecturer equal to 0,998 indicate that every improvement of work motivation score and organizational culture together will improve professional attitude of lecturer.

The results obtained for the coefficient of determination $\mathrm{R}_{\mathrm{y} .1 .2^{2}}$ of the correlation between the motivation of lecturer work and organizational culture together with professional attitude of lecturer amounted to 0.998 . This means that $99.8 \%$ professional attitude of lecturers is the result of the working motivation of lecturers and organizational culture together, while $0.2 \%$ is contributed by other variables that have relationship with improvement of professional attitude of lecturer. The findings obtained in this study indicate that if the lecturer in performing their duties and functions have the desire, the motive and eager in carrying out their duties because it has fulfilled their needs, and together the school organization has a system of shared meaning to the values that are able to create and facilitate the emergence of commitment and function as dominant values that have the main characteristics, the lecturer will be able to improve his professional attitude.

This is in accordance with the theories put forward by Kanfer Ruth and Gilad Chen on work motivation and by Stepen P.Robbin on organizational culture which each conveys his theory as in the previous discussion and can be diresumekan that the higher the motivation of work and organizational culture the higher the results professional attitude of lecturer.

Thus, a lecturer who has high work motivation and organizational culture together will be able to improve the professional attitude of lecturers.

The tendency that can be seen from the result of this research is correlation between work motivation of lecturer with professional attitude of lecturer that is $r_{\mathrm{y} 1}$ $=0,948$ when compared with correlation between organizational culture with professional attitude of lecturer $\mathrm{r}_{\mathrm{y} 2}=0,998$ above but almost approaching, however both independent variable respectively or together can contribute to the improvement of professional attitude of lecturers. The results of this study indicate that the desire for the award is realized in the implementation of work with a process oriented and the results of work of a high standard or quality, so that at the level of work will be felt optimally which then leads to the form of awards that are expected or given by the college organization high. Further professional attitudes are translated into work as a form of need to maximize the potential of self, a desire to realize the ability or potential of self and the desire to become what is perceived by someone because it has the ability or potential self to achieve it. The desire based on self potential is reflected in the work behavior by showing the various knowledge and skills of the work so that it can meet the applicable work requirements optimally.

The need to develop in the level of work is actualized in the form of a high curiosity and the desire to explore the knowledge and skills related to the occupied field of work. However, the correlation coefficient becomes higher if the two variables namely work motivation and organizational culture together to professional attitude variable of lecturer, that is 
correlation coefficient between work motivation and organizational culture $\mathrm{r} 1.2=0,998$. This implies that the work motivation of lecturers and organizational culture together is a factor to be able to achieve professional attitude of lecturers maximally

\section{CONCLUSION}

Based on the results of data analysis, statistical calculations, hypothesis testing and discussion can be concluded that the results of research on the relationship between the motivation of lecturer work and organizational culture with professional attitude of lecturer, at Pakuan University are as follows:

1. There is a positive relationship between the motivation of lecturer work with professional attitude of lecturer, meaning that the higher the motivation of the lecturer work the higher the professional attitude of the lecturer.

2. There is a positive relationship between organizational culture with professional attitude of lecturer, meaning the higher the organizational culture the higher the professional attitude of the lecturer.

3. There is a positive relationship between the motivation of lecturer work and organizational culture together with the professional attitude of the lecturer, meaning that the higher the work motivation and organizational culture together, the higher the professional attitude of the lecturer.

From the research in the field, it is found that in relation to the improvement of professional attitude of lecturers, there are free variables which have weak elements as follows: a) Work motivation variable: some lecturers assess the formal rights received are not sufficient as implementation of indicator of desire obtaining formal rights fairly, and still have not been given more roles and responsibilities as the implementation of an indicator of personal responsibility; b) organizational culture variables: some programs do not have a system that encourages employees to improve the effectiveness and efficiency of work as an implementation of the indicator of attention to the work, and still do not have a strategy that supports the development of creativity as the implementation of the indicators of innovation in the work.

Based on these conclusions, the professional attitude of lecturers, at Pakuan University can be improved through the improvement of work motivation of lecturers and organizational culture of the study program.

\section{REFERENCES}

Azwar Saifuddin. 2007. Sikap Manusia. Yogyakarta: Pustaka Pelajar.
Bennet Silalahi. 2004 Corporate Culture and Performance Appraisal. Jakarta : Al-Hambra.

Graves, Desmond. 1986. Organization Behavior McGraw Hill, Inc. New York,

M. Hasibuan. 2003. Manajemen Sumber Daya Manusia. Jakarta: Erlangga

M. Uzer Usman. 2005. Menjadi Guru Profesional Bandung : Remaja Rosdakarya.

Muhibin Syah. 2003. Psikologi Pendidikan Dengan Pendekatan Baru. Bandung: PT Remaja Rosdakarya.

Mukhtar dan Ervin A. Priambodo. 2001. Mengukir Prestasi: Panduan Menjadi Guru Profesional, Jakarta: Misaka Galiza.

Robbins, S. P. 2003. Organizational Behavior, New Jersey: Pearson Education International.

Schein, Edgar H. 1992. Organizational Culture and Leadershif. San Fransisco : Josseybass Publ.

Sudarwan Danim. 2003. Menjadi Komunitas Pembelajar. Jakarta : Bumi Aksara.

Susilo Martoyo. 2000. Manajemen Sumberdaya Manusia. Yogyakarta : BPFE. 